\title{
Effect of non-invasive prenatal testing as a contingent approach on the indications for invasive prenatal diagnosis and prenatal detection rate of Down's syndrome
}

\author{
KO Kou, CF Poon, SL Kwok, Kelvin YK Chan, Mary HY Tang, Anita SY Kan, KY Leung *
}

\section{A B S T R A C T}

Introduction: In Hong Kong, universal combined first-trimester screening for Down's syndrome was started as a 'free service' in July 2010. Non-invasive prenatal testing was available as a self-financed item in August 2011. This study aimed to determine whether the introduction of non-invasive prenatal testing as a contingent approach influenced the indications for invasive prenatal diagnosis and the consequent prenatal detection of Down's syndrome.

Methods: This historical cohort study was conducted at the Prenatal Diagnosis Clinic of Queen Elizabeth Hospital in Hong Kong. We compared the indications for invasive prenatal diagnosis and prenatal detection of Down's syndrome in singleton pregnancies 1 year before and 2 years following the availability of non-invasive prenatal testing as a contingent test after a positive aneuploidy test. All pregnant women who attended our hospital for counselling about universal Down's syndrome screening between August 2010 and July 2013 were recruited.

Results: A total of 16098 women were counselled. After the introduction of non-invasive prenatal testing, the invasive prenatal diagnosis rate for a positive aneuploidy screening reduced from $77.7 \%$ in $2010-11$ to $68.8 \%$ in $2012-13$. The new combined conventional plus non-invasive prenatal testing strategy was associated with a lower false-

This article was published on 6 May 2016 at www.hkmj.org. positive rate $(6.9 \%$ in $2010-11$ vs $5.2 \%$ in $2011-12$ and $4.9 \%$ in 2012-13). There was no significant increase in invasive prenatal diagnosis for structural anomalies over the years. There was no significant trend in the overall prenatal detection rate of Down's syndrome (100\% 1 year before vs $89.1 \% 2$ years after introduction of non-invasive prenatal testing). Four (2.6\%) of 156 women who underwent non-invasive prenatal testing for a screen-positive result had a high-risk result for trisomy 21, which was subsequently confirmed by invasive prenatal diagnosis. There were no false-negative cases.

Conclusion: The introduction of non-invasive prenatal testing as a contingent approach reduced the invasive prenatal diagnosis rate for a positive aneuploidy screening without affecting the invasive prenatal diagnosis rate for structural anomalies or the overall detection rate of fetal Down's syndrome.

\section{Hong Kong Med J 2016;22:223-30 \\ DOI: $10.12809 / \mathrm{hkmj} 154730$}

${ }^{1}$ KO Kou, MRCOG, FHKAM (Obstetrics and Gynaecology)

${ }^{1}$ CF Poon, MSc Health Care (Nursing), RDMS (OB/GYN \& FE)

${ }^{1}$ SL Kwok, RNM, Master of Nursing (Clinical Leadership)

${ }^{2}$ KYK Chan, BSc, PhD

${ }^{2}$ MHY Tang, FRCOG, FHKAM (Obstetrics and Gynaecology)

${ }^{2}$ ASY Kan, MRCOG, FHKAM (Obstetrics and Gynaecology)

${ }^{1}$ KY Leung *, MD, FHKAM (Obstetrics and Gynaecology)

Department of Obstetrics and Gynaecology, Queen Elizabeth Hospital, Jordan, Hong Kong

2 Prenatal Diagnostic Laboratory, Tsan Yuk Hospital and Department of Obstetrics and Gynaecology, Queen Mary Hospital, Hong Kong

* Corresponding author: leungky1@ha.org.hk

New knowledge added by this stud

- Introduction of non-invasive prenatal testing (NIPT) decreased overall invasive prenatal diagnosis (IPD) rate for a positive aneuploidy screening without affecting the IPD rate for structural anomalies.

NIPT as a contingent approach does not affect the overall detection rate of fetal Down's syndrome.

Implications for clinical practice or policy

NIPT provides a safe contingent approach for a positive aneuploidy screening. This is particularly relevant in centres with a high false-positive rate following conventional screening for Down's syndrome.

- Extending the indications of NIPT from high-risk to intermediate- or low-risk women with a view to increasing the prenatal detection rate of Down's syndrome requires further evaluation.

\section{Introduction}

Over the last 30 years, there has been a shift in clinical practice away from performing an invasive prenatal diagnosis (IPD) on the basis of maternal age to a non-invasive screening method $^{1-5}$ with improving performance. ${ }^{6-12}$ Initially, the introduction 


\section{作為權變選擇的非侵入性產前染色體檢測對於侵 入性產前診斷和唐氏綜合症產前檢出率的影響}

高錦安、潘仲芬、郭淑玲、陳遠光、唐海燕、簡適悠、梁國賢

引言：香港於2010年7月開始為所有孕婦提供免費的早孕期唐氏綜合 症篩查服務, 於2011年8月亦開始提供自費式非侵入性產前染色體檢 測（NIPT）。本研究旨在探討作為權變選擇的NIPT對於侵入性產前 診斷和唐氏綜合症產前檢出率的影響。

方法：本歷史隊列研究在香港伊利沙伯醫院的產前診斷中心內進行。 我們比較NIPT服務推出前 1 年和推出後 2 年, 當單胎㝋婦的非整倍體 測試呈陽性時, 上述診所的侵入性產前診斷和唐氏綜合症產前檢出 率。2010年8月至2013年7月期間到上述診所接受有關唐氏綜合症產 前測試輔導服務的所有孕婦均被納入研究範圍。

結果：研究期間共 16098 名孕婦接受輔導服務。NIPT服務推出後, 非整倍體測試呈陽性的侵入性產前診斷由2010-11年的7 7.7\%下降至 2012-13年的68.8\%。合併傳統以及NIPT的策略與較低假陽性率相關 （2010-11年的6.9\%比2011-12年的5.2\%及2012-13年的4.9\%）。兩 段時間的唐氏綜合症產前檢出率並沒有明顯分別：NIPT服務推出前 1 年的檢出率為 $100 \%$, NIPT服務推出後 2 年則為 $89.1 \%$ 。1 56 名因非整 倍體測試呈陽性而接受NIPT的孕婦中，4例（2.6\%）有T21高風險結 果, 最終以侵入性產前診斷確診為唐氏綜合症。研究中並無發現假陰 性病例。

結論：NIPT既能減低非整倍體測試陽性病例的侵入性產前診斷率，亦 不會影響有結構異常的病例的侵入性產前診斷率或唐氏綜合症總檢出 率。 as before, we aimed to review all the indications for IPD and to determine any alteration in the overall prenatal detection of Down's syndrome before and after the introduction of NIPT as a contingent approach.

\section{Methods}

This historical cohort study was conducted at the Prenatal Diagnosis Clinic of Queen Elizabeth Hospital, Hong Kong. All pregnant women who attended our hospital for counselling on prenatal testing for Down's syndrome between August 2010 and July 2013 were recruited. The utilisation of conventional screening, NIPT, and IPD for Down's syndrome and other aneuploidies in all singleton pregnancies were included. Our hospital is one of the largest referral public hospitals in Hong Kong with around 6000 deliveries a year. This study was approved by the Research Ethics Committee of Kowloon Central/Kowloon East Cluster, Hong Kong. Informed consent was not required for this retrospective study.

Since 1 July 2010, universal prenatal screening for Down's syndrome with cFTS between 11 weeks and 13 weeks and 6 days or STS has been offered to all pregnant women after adequate counselling. Combined first-trimester screening includes fetal nuchal translucency (NT) measurement, and free beta-human chorionic gonadotrophin and pregnancy-associated plasma protein-A assessment. The gestational age is determined by an ultrasound examination (crown rump length in the first or head biometry in the second trimester) shortly after the first antenatal visit.

All NT measurements were performed by trained midwives and doctors who were Fetal Medicine Foundation-certified or accredited as maternal fetal medicine (MFM) subspecialists. In our hospital, MFM team doctors counselled screen-positive (risk $\geq 1$ in 250 in cFTS) women about different options including IPD with CVS or amniocentesis, or no further prenatal invasive testing. After August 2011, the option of selffinanced NIPT was also discussed at the request of patients.

Most commercial NIPT was based on massively parallel sequencing with 'shotgun' counting of all cell-free DNA sequences while others involve 'targeted' counting of specific DNA sequences. A usual NIPT report includes the risk for trisomies 21, 18 , and 13. Sex chromosomal or other abnormalities are also reported if identified on NIPT. If NIPT demonstrated a high risk for trisomy 21,18 or 13 , confirmatory IPD was required. After undergoing NIPT in the private sector, the woman would be followed up, counselled by doctors, rescanned for any structural fetal anomaly and offered an option of invasive testing, regardless of the results of NIPT, 
at no charge. We advised women with fetal NT $\geq 3.5$ $\mathrm{mm}$ or structural abnormalities to undergo IPD rather than NIPT given their higher risk of atypical chromosome abnormalities that might not be picked up by the latter. ${ }^{17}$ In addition, IPD would be offered (a) if first-trimester or routine mid-trimester anomaly scan showed an abnormality, (b) for genetic diseases like thalassaemia, (c) if there was a positive family history, or (d) rarely, if there was maternal anxiety after adequate counselling.

Chromosome analysis was mainly performed by the prenatal diagnostic laboratory of Tsan Yuk Hospital and a small proportion at Prince of Wales Hospital, Hong Kong. These two laboratories are accredited by professional bodies in providing prenatal diagnostic tests and serve the local obstetric units. Analyses included G-banding chromosome analyses and quantitative fluorescence polymerase chain reaction for rapid aneuploidy detection. All pregnancy outcomes were traced by reviewing hospital records or phone contact in women who delivered outside this hospital.

We determined the number of fetuses and newborns with Down's syndrome prenatally or postnatally, the rate of different prenatal tests for Down's syndrome, and the number of IPD that were needed to diagnose one fetus with Down's syndrome. We also reviewed the indications for IPD and classified them as one of the following priorities: high risk for trisomy 21, 18, 13 or other aneuploidy on NIPT, increased NT $(\geq 3.5 \mathrm{~mm})$, structural anomalies on ultrasound, parental carrier of or previous pregnancies with abnormal karyotype, positive aneuploidy screening, maternal age $\geq 35$ years, or others. If NT was increased and cFTS trisomy 21 risk was high, increased NT would be selected as the sole indication for IPD.

\section{Statistical analyses}

With the use of descriptive statistics and Chi squared test for linear trend, the rates of conventional screening, NIPT, IPD, and prenatally diagnosed Down's syndrome were compared 1 year before and 2 years after NIPT introduction. All statistical analyses were performed using the Statistical Package for the Social Sciences (Windows version 21.0; SPSS Inc, Chicago [IL], US).

\section{Results}

A total of 16098 women with singleton pregnancies were counselled on prenatal testing for Down's syndrome. Although the total proportion of women who underwent screening remained around 97\% from 2010 to 2013, cFTS increased from $84.4 \%$ in 2010-11 to $90.5 \%$ in $2012-13$ and STS decreased from $12.1 \%$ to $7.1 \%$ in the same period $(\mathrm{P}<0.001)$ [Table 1]. With a sharp increase in the use of NIPT in the screen-positive group $(0 \%, 0.8 \%$, and $1.9 \%$ in 2010-11, 2011-12, 2012-13, respectively; $\mathrm{P}<0.001$ ), the rate of IPD and CVS dropped from $7.6 \%$ and $4.2 \%$ in $2010-11$ to $6.0 \%$ and $2.5 \%$ in $2012-13$, respectively while the amniocentesis rate fluctuated. The actual number of IPD remained similar over the

TABLE I. Trend analysis for number of a variety of tests in women who attended prenatal diagnosis and counselling clinic from August 2010 to July 2013

\begin{tabular}{|c|c|c|c|c|c|}
\hline & Total $(n=16098)$ & $\begin{array}{c}\text { Aug } 2010-\text { Jul } 2011 \\
(n=4440)\end{array}$ & $\begin{array}{c}\text { Aug } 2011-\text { Jul } \\
(n=5904)\end{array}$ & $\begin{array}{c}\text { Aug } 2012-\mathrm{Jul} \\
(\mathrm{n}=5754)\end{array}$ & P value ${ }^{\star}$ \\
\hline Screening & $15632(97.1 \%)$ & $4288(96.6 \%)$ & $5726(97.0 \%)$ & $5618(97.6 \%)$ & \\
\hline cFTS & $14144(87.9 \%)$ & $3749(84.4 \%)$ & $5188(87.9 \%)$ & $5207(90.5 \%)$ & $<0.001$ \\
\hline STS & $1488(9.2 \%)$ & $539(12.1 \%)$ & $538(9.1 \%)$ & $411(7.1 \%)$ & $<0.001$ \\
\hline Screened positive & $1069(6.8 \%)$ & $306(7.1 \%)$ & $362(6.3 \%)$ & $401(7.1 \%)$ & 0.151 \\
\hline cFTS & $957(6.8 \%)$ & $270(7.2 \%)$ & $330(6.4 \%)$ & $357(6.9 \%)$ & \\
\hline STS & $112(7.5 \%)$ & $36(6.7 \%)$ & $32(5.9 \%)$ & $44(10.7 \%)$ & \\
\hline False positive & $1016(6.5 \%)$ & $294(6.9 \%)$ & $343(6.0 \%)$ & $379(6.7 \%)$ & 0.142 \\
\hline NIPT for positive cFTS or STS & $156(1.0 \%)$ & 0 & $49(0.8 \%)$ & $107(1.9 \%)$ & $<0.001$ \\
\hline NIPT positive & 4 & 0 & 1 & 3 & \\
\hline Reduction in false positive & $152(15.0 \%)$ & 0 & $48(14.0 \%)$ & $104(27.4 \%)$ & \\
\hline Final false positive (\%) & $5.5 \%$ & $6.9 \%$ & $5.2 \%$ & $4.9 \%$ & \\
\hline IPD & $1020(6.3 \%)$ & $337(7.6 \%)$ & $337(5.7 \%)$ & $346(6.0 \%)$ & 0.03 \\
\hline Amniocentesis & $494(3.1 \%)$ & $152(3.4 \%)$ & 139 (2.4\%) & 203 (3.5\%) & 0.03 \\
\hline CVS & $526(3.3 \%)$ & $185(4.2 \%)$ & 198 (3.4\%) & 143 (2.5\%) & 0.04 \\
\hline
\end{tabular}

Abbreviations: cFTS = combined first-trimester screening; CVS = chorionic villus sampling; IPD = invasive prenatal diagnosis; NIPT = non-invasive prenatal testing; STS = second-trimester screening

* Chi squared test for linear trend 
years though the rate declined, probably because of an increasing number of screenings from 4288 in 2010-11 to 5618 in 2012-13 (Table 1).

\section{Indications for invasive prenatal diagnosis}

There was a significant decrease in IPD for positive aneuploidy screening from $77.7 \%$ in $2010-11$ to $68.8 \%$ in $2012-13$ ( $\mathrm{P}=0.005)$. There was no significant increase in IPD for structural anomalies over the years (Table 2).

\section{Prenatal detection of Down's syndrome}

There was no significant trend in the overall prenatal diagnosis/detection rate of Down's syndrome before and after the availability of NIPT (Table 3 ). The number of IPD required to diagnose one case of Down's syndrome decreased from 28 to 16 over the same period of time, though the trend was not significant, probably because of the small sample size (Table 3). There were nine newborn infants with Down's syndrome over the 3 years. In two cases, women declined IPD despite a positive Down's syndrome screening result. In another two cases that were included in the 45 diagnosed prenatally, women chose to continue their pregnancy after IPD of Down's syndrome. The remaining five cases were screened negative and diagnosed postnatally (Fig).

\section{Performance of non-invasive prenatal testing}

Four (2.6\%) of 156 women who underwent NIPT for a screen-positive result (cFTS or STS being 1 in 3, 1 in 25,1 in 45 and 1 in 230) were considered at high risk for trisomy 21 (increased amount of chromosome 21 DNA molecules in a maternal sample compared with that of a euploid reference sample); all results were confirmed on subsequent IPD. One woman

TABLE 2. Trend analysis for number of invasive prenatal diagnosis performed from August 2010 to July 2013 with various clinical indications and subgroup analysis for screen-positive results and maternal age $\geq 35$ years

\begin{tabular}{|c|c|c|c|c|c|c|}
\hline Indication for IPD & $\begin{array}{l}\text { Down's syndrome } \\
\text { diagnosed }\end{array}$ & $\begin{array}{l}\text { Total No. of IPD } \\
(n=1020)\end{array}$ & $\begin{array}{l}\text { Aug } 2010-\text { Jul } \\
2011(n=337)\end{array}$ & $\begin{array}{l}\text { Aug } 2011-\text { Jul } \\
2012(n=337)\end{array}$ & $\begin{array}{l}\text { Aug } 2012-\text { Jul } \\
2013(n=346)\end{array}$ & P value* \\
\hline Screen-positive results & $24(3.3 \%)$ & $736(72.2 \%)$ & $262(77.7 \%)$ & $236(70.0 \%)$ & 238 (68.8\%) & 0.005 \\
\hline Increased NT & $21(26.3 \%)$ & $80(7.8 \%)$ & $13(3.9 \%)$ & $37(11.0 \%)$ & $30(8.7 \%)$ & 0.016 \\
\hline Structural anomaly & $4(3.6 \%)$ & $110(10.8 \%)$ & $33(9.8 \%)$ & $38(11.3 \%)$ & $39(11.3 \%)$ & 0.730 \\
\hline Family history/genetics $†$ & 0 & $40(3.9 \%)$ & $11(3.3 \%)$ & $16(4.7 \%)$ & $13(3.8 \%)$ & 0.601 \\
\hline Anxiety & 0 & $50(4.9 \%)$ & $18(5.3 \%)$ & $9(2.7 \%)$ & $23(6.6 \%)$ & 0.05 \\
\hline NIPT high risk & $4(100 \%)$ & $4(0.4 \%)$ & 0 & $1(0.3 \%)$ & 3 (0.9\%) & 0.183 \\
\hline
\end{tabular}

Abbreviations: IPD = invasive prenatal diagnosis; NIPT = non-invasive prenatal testing; NT = nuchal translucency

* Chi squared test for linear trend

$\dagger$ Family history $=$ previous pregnancy or parental carrier

TABLE 3. Trend analysis for number and prenatal detection rate of Down's syndrome, and number of invasive prenatal diagnosis required to diagnose one DS case

\begin{tabular}{|c|c|c|c|c|c|}
\hline & Total & $\begin{array}{c}\text { Aug } 2010-\mathrm{Jul} \\
2011\end{array}$ & $\begin{array}{c}\text { Aug } 2011 \text { - Jul } \\
2012\end{array}$ & $\begin{array}{c}\text { Aug } 2012-\mathrm{Jul} \\
2013\end{array}$ & P value $^{\star}$ \\
\hline DS cases (risk in screened population) & $58(1$ in 304) & $12(1$ in 370$)$ & $22(1$ in 311$)$ & 24 (1 in 262) & 0.447 \\
\hline Prenatally diagnosed or detected DS cases ( $\%$ of DS cases) $\dagger$ & $53(91.4 \%)$ & $12(100.0 \%)$ & $19(86.4 \%)$ & $22(91.7 \%)$ & 0.399 \\
\hline No. of IPD needed to diagnose one DS overall & $19(1020 / 53)$ & $28(337 / 12)$ & $18(337 / 19)$ & $16(346 / 22)$ & 0.171 \\
\hline \multicolumn{6}{|l|}{ Among those } \\
\hline Screened positive & $31(736 / 24)$ & $44(262 / 6)$ & $26(236 / 9)$ & $27(238 / 9)$ & \\
\hline Increased NT & $4(80 / 21)$ & $2(13 / 6)$ & $5(37 / 7)$ & $4(30 / 8)$ & \\
\hline Structural anomaly & $28(110 / 4)$ & - $(33 / 0)$ & $19(38 / 2)$ & $20(39 / 2)$ & \\
\hline NIPT high risk & $1(4 / 4)$ & - & $1(1 / 1)$ & $1(3 / 3)$ & \\
\hline
\end{tabular}

Abbreviations: DS = Down's syndrome; IPD = invasive prenatal diagnosis; NIPT = non-invasive prenatal testing; NT = nuchal translucency

* Chi squared test for linear trend

† In two cases (one in 201 I-12, the other in 2012-13), women declined IPD despite a positive DS screening result. In another two cases (one in 20 I0- I I, and the other in 2011-12), women chose to continue their pregnancy after IPD of DS 


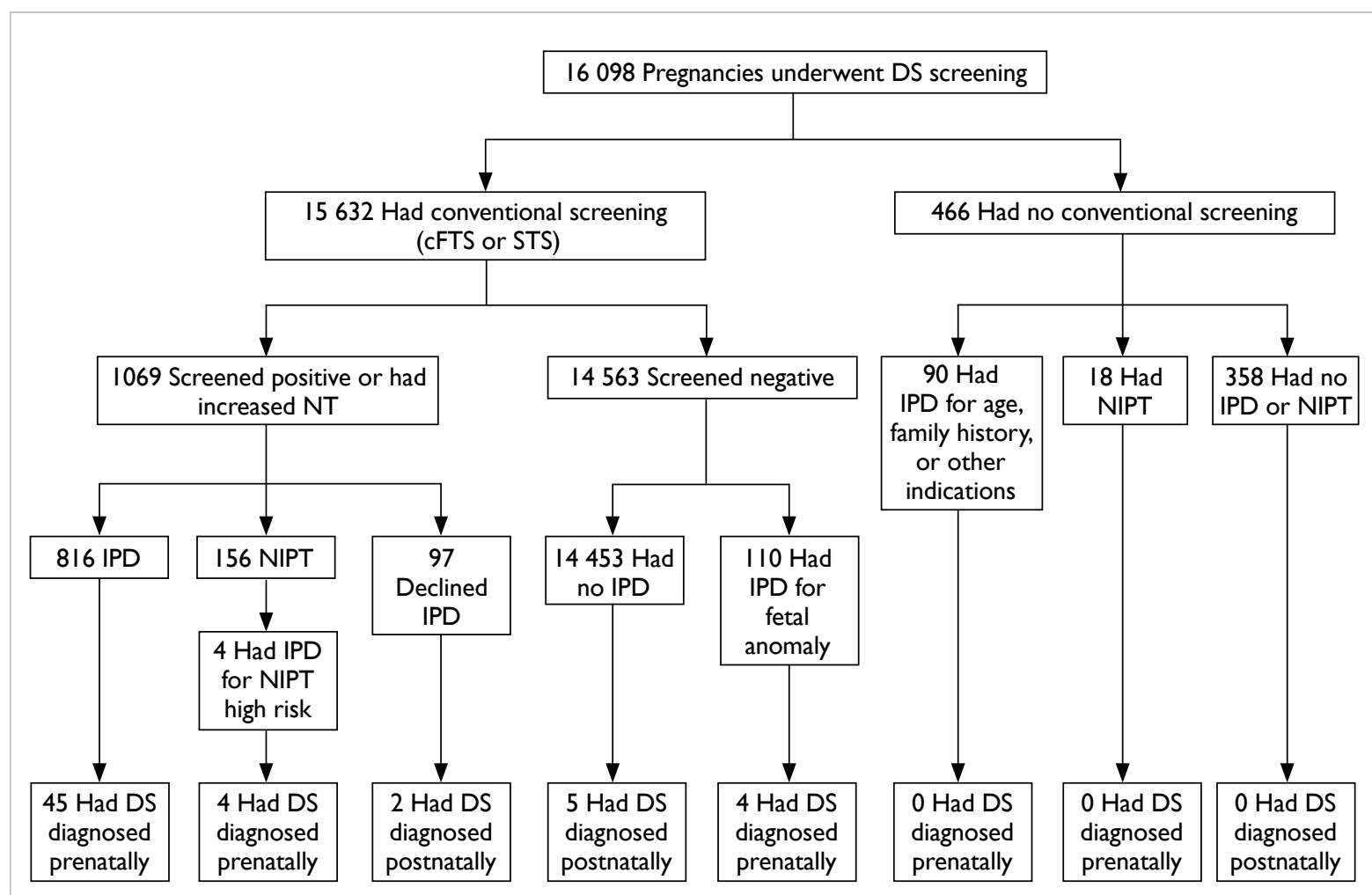

FIG. Number of fetuses and newborns with DS diagnosed prenatally or postnatally according to different screening tests Abbreviations: cFTS = combined first-trimester screening; DS = Down's syndrome; IPD = invasive prenatal diagnosis; NIPT = non-invasive prenatal testing; NT = nuchal translucency; STS = second-trimester screening

who had a positive aneuploidy screening but a lowrisk NIPT result underwent IPD and had normal fetal karyotype. There were no false-negative results and all babies were confirmed normal after delivery by routine clinical examination.

\section{Performance of conventional screening}

The overall screen-positive and false-positive rates were $6.8 \%$ and $6.5 \%$ respectively, and were similar over the 3 -year period (Table 1 ).

With an increasing number of NIPT as secondary screening performed for positive cFTS/ STS, the false-positive rate of screening decreased from $6.9 \%$ in $2010-11$ to $5.2 \%$ in $2011-12$ and $4.9 \%$ in 2012-13. In 2012-13, with 107 NIPT performed for a positive cFTS or STS, the false-positive rate decreased by $29.0 \%$ from $6.9 \%$ to $4.9 \%$.

The cFTS risk of the five cases of Down's syndrome not diagnosed prenatally was 1 in 300, 690, 770,7300 , and 7300. In other words, the risk of three out of these five cases was below 1 in 1000. All five women were younger than 35 years. Among those screened negative, four cases of Down's syndrome were diagnosed prenatally by IPD performed for fetal anomaly (Fig). In one of these four cases, midtrimester scan showed subtle sonographic signs including absent nasal bone and persistent left superior vena cava.

\section{Discussion}

As shown in other studies ${ }^{5,14}$ and our previous study, ${ }^{16}$ the introduction of NIPT was accompanied by a decrease in IPD rate. In the present study, we have further shown that the introduction of NIPT reduced the IPD rate for positive aneuploidy screening without affecting the prenatal detection of Down's syndrome. Consistent with previous studies, ${ }^{5,13,14}$ there was a rapid uptake of NIPT, probably because of its non-invasive nature and high sensitivity and specificity for common aneuploidies. ${ }^{6}$ A local study showed that NIPT results could reduce women's uncertainty associated with risk probability-based results from conventional screening. ${ }^{18}$ Women are willing to pay for a test that has a lower false-positive rate. ${ }^{19}$

We could not exclude the possibility that the reduction in IPD rate might be partially related to an increase in the proportion of cFTS with a lower 
false-positive rate than STS. $^{3}$ Nevertheless, we observed no significant increase in IPD performed for structural anomalies despite a concern about missing atypical chromosomal abnormalities with NIPT alone. ${ }^{17,20,21}$

The benefit of reducing the IPD rate is particularly relevant to our screening programme as the overall screen-positive rate of our conventional screening programme was $6.8 \%$, which is higher than the published figures of $3.3 \%$ to $5.9 \% .{ }^{4,22-26}$ With increasing use of NIPT as secondary screening for a positive result of $\mathrm{cFTS} / \mathrm{STS}$, the false-positive rate was reduced. The improvement was encouraging even before full implementation of the strategy using NIPT as a secondary screening tool.

Assuming $1.8 \%$ reduction in IPD (7.6\% in 2010-11 - mean of 5.7\% in 2011-12 and 6.0\% in 201213; Table 1) as in our present study, an annual delivery rate of 50000 in Hong Kong, and 1\% miscarriage rate associated with IPD, we estimate that around 900 IPDs or nine miscarriages can be potentially avoided if this contingent approach is adopted widely. This reduction in IPD-related miscarriage could be further improved as theoretically about 98\% of the IPD for positive aneuploidy screening could be avoided if NIPT was used by all screenpositive women. ${ }^{27}$ Nonetheless, $1.8 \%$ ([1020 736]/16 098) of IPD (Table 2) were still required for other indications including increased NT or structural anomalies, even if all screen-positive women opted for NIPT. Alternatively, the screenpositive rate could be reduced by changing the cut-off value from 1 in 250 to 1 in 150,2 improving the quality assurance of measurement of NT (www. fetalmedicine.com) and laboratory assays of serum markers, algorithms in calculation of trisomy 21 risk, and adding sonographic markers. ${ }^{4,28}$

The prenatal detection rate of Down's syndrome in the present study was similar to the published results of $83 \%$ to $93 \% .{ }^{4,22-26}$ In contrast to cFTS and STS that have been used in primary screening and resulted in a reduction in the number of live births with Down's syndrome, ${ }^{1,4}$ introduction of NIPT did not improve the detection rate of our screening programme. This is expected as NIPT is currently not routinely used for primary screening. Nevertheless, NIPT did not decrease the detection rate of Down's syndrome as there was no false-negative rate for NIPT in the present small study. There was concern about missing atypical abnormalities with NIPT alone. ${ }^{17,20,21}$ Further studies are required.

In keeping with international guidelines, ${ }^{29-32}$ we suggest offering NIPT as an option to women with positive aneuploidy screening alone without increased NT or structural abnormalities to avoid an unnecessary IPD and its associated miscarriage risk. We also recommend improving the prenatal detection rate of a screening programme for Down's syndrome by adjusting the cut-off value for cFTS, for example, from 1 in 250 to 1 in 1000, rather than offering it to all women as a primary screening..$^{33}$ In our unit, the detection rate would be improved from $91.4 \%$ to $96.6 \%$ as cFTS risk of three of our five missed cases of Down's syndrome were above 1 in 1000. As such, NIPT would be offered to $16.9 \%$ of women, including $6.8 \%$ with cFTS risk $\geq 1$ in 250 and $10.1 \%$ with risk $>1$ in 1000 but $<1$ in 250. Offering an additional option of NIPT to women with advanced maternal age only did not improve the detection rate based on the results of the present study, probably because all five missed cases were younger than 35 years and sample size was small. Careful analysis with accurate assumptions, including the uptake rate of cFTS, and NIPT, the number of IPD avoided, cut-off value for cFTS, decreasing charges of NIPT with time, ${ }^{34}$ and other issues is required to determine the costeffectiveness of incorporating NIPT into the current screening programme for Down's syndrome. . $2035^{23}$ Major governing or professional bodies recommend NIPT in the context of informed consent, education, and pre- and post-test counselling. ${ }^{29-32,36}$ In our previous study, ${ }^{37}$ we showed that Chinese women who underwent NIPT recognised the limitations, but did not understand the complicated aspects. We suggest giving more information by health care professionals, preferably trained midwives, so that patients can make an informed choice. ${ }^{37}$

The limitations of the present study included its retrospective nature, single-centre, and small sample size. The actual performance of NIPT could not be examined as not all eligible subjects were tested. Availability and payment methods for NIPT and other prenatal testing, cut-off level of cFTS, and women's preferences differ in different places. Thus, generalisation of the results of the present study should be done with caution.

\section{Conclusion}

The introduction of NIPT as a contingent approach reduced the IPD rate for positive aneuploidy screening without increasing the IPD rate for scan abnormalities or affecting the overall prenatal detection rate of Down's syndrome. This fall in IPD rate was particularly relevant in our centre with a high false-positive rate after cFTS.

\section{Acknowledgements}

We would like to thank the prenatal diagnostic laboratory of Tsan Yuk Hospital and Prince of Wales Hospital, Hong Kong for performing the chromosome analysis.

\section{Declaration}

All authors have disclosed no conflicts of interest. 


\section{References}

1. Cheffins T, Chan A, Haan EA, et al. The impact of maternal serum screening on the birth prevalence of Down's syndrome and the use of amniocentesis and chorionic villus sampling in South Australia. BJOG 2000;107:14539.

2. Morgan S, Delbarre A, Ward P. Impact of introducing a national policy for prenatal Down syndrome screening on the diagnostic invasive procedure rate in England. Ultrasound Obstet Gynecol 2013;41:526-9.

3. Muller PR, Cocciolone R, Haan EA, et al. Trends in state/ population-based Down syndrome screening and invasive prenatal testing with the introduction of first-trimester combined Down syndrome screening, South Australia, 1995-2005. Am J Obstet Gynecol 2007;196:315.e1-7; discussion 285-6.

4. Ekelund CK, Jørgensen FS, Petersen OB, Sundberg K, Tabor A; Danish Fetal Medicine Research Group. Impact of a new national screening policy for Down's syndrome in Denmark: population based cohort study. BMJ 2008;337:a2547.

5. Chetty S, Garabedian MJ, Norton ME. Uptake of noninvasive prenatal testing (NIPT) in women following positive aneuploidy screening. Prenat Diagn 2013;33:5426.

6. Norton ME, Brar $\mathrm{H}$, Weiss J, et al. Non-Invasive Chromosomal Evaluation (NICE) Study: results of a multicenter prospective cohort study for detection of fetal trisomy 21 and trisomy 18. Am J Obstet Gynecol 2012;207:137.e1-8.

7. Palomaki GE, Kloza EM, Lambert-Messerlian GM, et al. DNA sequencing of maternal plasma to detect Down syndrome: an international clinical validation study. Genet Med 2011;13:913-20.

8. Bianchi DW, Platt LD, Goldberg JD, Abuhamad AZ, Sehnert AJ, Rava RP; MatErnal BLood IS Source to Accurately diagnose fetal aneuploidy (MELISSA) Study Group. Genome-wide fetal aneuploidy detection by maternal plasma DNA sequencing. Obstet Gynecol 2012;119:890901.

9. Evans MI, Wright DA, Pergament E, Cuckle HS, Nicolaides KH. Digital PCR for noninvasive detection of aneuploidy: power analysis equations for feasibility. Fetal Diagn Ther 2012;31:244-7.

10. Malone FD, Canick JA, Ball RH, et al. First-trimester or second-trimester screening, or both, for Down's syndrome. N Engl J Med 2005;353:2001-11.

11. Wald NJ. Prenatal screening for open neural tube defects and Down syndrome: three decades of progress. Prenat Diagn 2010;30:619-21.

12. Rozenberg P, Bussières L, Chevret S, et al. Screening for Down syndrome using first-trimester combined screening followed by second-trimester ultrasound examination in an unselected population. Am J Obstet Gynecol 2006;195:1379-87.

13. Larion S, Romary L, Mlynarczyk M, Abuhamad AZ, Warsof SL. Changes in prenatal testing trends after introduction of noninvasive prenatal testing. Obstet Gynecol 2014;123 Suppl 1:62S-63S.

14. Larion S, Warsof SL, Romary L, Mlynarczyk M, Peleg D, Abuhamad AZ. Uptake of noninvasive prenatal testing at a large academic referral center. Am J Obstet Gynecol 2014;211:651.e1-7.
15. Musci TJ, Fairbrother G, Batey A, Bruursema J, Struble C, Song K. Non-invasive prenatal testing with cell-free DNA: US physician attitudes toward implementation in clinical practice. Prenat Diagn 2013;33:424-8.

16. Poon CF, Tse WC, Kou KO, Leung KY. Uptake of noninvasive prenatal testing in Chinese women following positive Down syndrome screening. Fetal Diagn Ther 2015;37:141-7.

17. Petersen OB, Vogel I, Ekelund C, Hyett J, Tabor A; Danish Fetal Medicine Study Group; Danish Clinical Genetics Study Group. Potential diagnostic consequences of applying non-invasive prenatal testing: populationbased study from a country with existing first-trimester screening. Ultrasound Obstet Gynecol 2014;43:265-71.

18. Yi H, Hallowell N, Griffiths S, Yeung Leung T. Motivations for undertaking DNA sequencing-based non-invasive prenatal testing for fetal aneuploidy: a qualitative study with early adopter patients in Hong Kong. PLoS One 2013;8:e81794.

19. Lo TK, Lai FK, Leung WC, et al. Screening options for Down syndrome: how women choose in real clinical setting. Prenat Diagn 2009;29:852-6.

20. van Landingham S, Bienstock J, Wood Denne E, Hueppchen $\mathrm{N}$. Beyond the first trimester screen: can we predict who will choose invasive testing? Genet Med 2011;13:539-44.

21. Benn P, Borell A, Chiu R, et al. Position statement from the Aneuploidy Screening Committee on behalf of the Board of the International Society for Prenatal Diagnosis. Prenat Diagn 2013;33:622-9.

22. Hadlow NC, Hewitt BG, Dickinson JE, Jacoby P, Bower C. Community-based screening for Down's Syndrome in the first trimester using ultrasound and maternal serum biochemistry. BJOG 2005;112:1561-4.

23. O'Leary P, Breheny N, Dickinson JE, et al. First-trimester combined screening for Down syndrome and other fetal anomalies. Obstet Gynecol 2006;107:869-76.

24. Soergel P, Pruggmayer M, Schwerdtfeger R, Muhlhaus K, Scharf A. Screening for trisomy 21 with maternal age, fetal nuchal translucency and maternal serum biochemistry at 11-14 weeks: a regional experience from Germany. Fetal Diagn Ther 2006;21:264-8.

25. Spencer K, Spencer CE, Power M, Dawson C, Nicolaides $\mathrm{KH}$. Screening for chromosomal abnormalities in the first trimester using ultrasound and maternal serum biochemistry in a one-stop clinic: a review of three years prospective experience. BJOG 2003;110:281-6.

26. Stenhouse EJ, Crossley JA, Aitken DA, Brogan K, Cameron AD, Connor JM. First-trimester combined ultrasound and biochemical screening for Down syndrome in routine clinical practice. Prenat Diagn 2004;24:774-80.

27. Chiu RW, Akolekar R, Zheng YW, et al. Non-invasive prenatal assessment of trisomy 21 by multiplexed maternal plasma DNA sequencing: large scale validity study. BMJ 2011;342:c7401.

28. Nicolaides KH. Screening for fetal aneuploidies at 11 to 13 weeks. Prenat Diagn 2011;31:7-15.

29. American College of Obstetricians and Gynecologists Committee on Genetics. Committee Opinion No. 545: Noninvasive prenatal testing for fetal aneuploidy. Obstet Gynecol 2012;120:1532-4.

30. Gregg AR, Gross SJ, Best RG, et al. ACMG statement on noninvasive prenatal screening for fetal aneuploidy. Genet Med 2013;15:395-8. 
31. Soothill PW, Lo YM. Non-invasive prenatal testing for chromosomal abnormality using maternal plasma DNA, Scientific Impact Paper No. 15. London, Royal College of Obstetricians and Gynaecologists; 2014.

32. Benn P, Borrell A, Chiu R, et al. Position Statement from the Chromosome Aneuploidy Screening Committee on behalf of the Board of the International Society for Prenatal Diagnosis. April 2015. Available from: https:// www.ispdhome.org/docs/ISPD/Society\%20Statements/ PositionStatement_Current_8Apr2015.pdf. Accessed 8 Oct 2015.

33. Benn P, Curnow KJ, Chapman S, Michalopoulos SN, Hornberger J, Rabinowitz M. An economic analysis of cellfree DNA non-invasive prenatal testing in the US general pregnancy population. PLoS One 2015;10:e0132313.

34. Shengmou L, Min C, Chenhong W, et al. Effects, safety and cost-benefit analysis of Down syndrome screening in first trimester [in Chinese]. Zhonghua Fu Chan Ke Za Zhi 2014;49:325-30.

35. Stoll K, Lutgendorf M, Knutzen D, Nielsen PE. Questioning the costs and benefits of non-invasive prenatal testing. J Matern Fetal Neonatal Med 2014;27:633-4.

36. Devers PL, Cronister A, Ormond KE, Facio F, Brasington CK, Flodman P. Noninvasive prenatal testing/noninvasive prenatal diagnosis: the position of the National Society of Genetic Counselors. J Genet Couns 2013;22:291-5.

37. Kou KO, Poon CF, Tse WC, Mak SL, Leung KY. Knowledge and future preference of Chinese omen in a major public hospital in Hong Kong after undergoing non-invasive prenatal testing for positive aneuploidy screening: a questionnaire survey. BMC Pregnancy Childbirth 2015;15:199. 